\title{
Morphological and biochemical characteristics during ovarian follicular development in the pig*
}

\author{
S. A. Grant, M. G. Hunter and G. R. Foxcroft $\uparrow$ \\ A.F.R.C. Research Group on Hormones and Farm Animal Reproduction, University of Nottingham, \\ Faculty of Agricultural Science, Sutton Bonington, Loughborough, Leics LE12 $5 R D, U K$
}

\begin{abstract}
Summary. Ovaries were recovered from groups of naturally cyclic pigs $(\mathrm{N}=5)$ on each of Days 16, 18, 20 and 21 of the oestrous cycle. Follicular diameter, follicular fluid volume and concentrations of oestradiol, testosterone and progesterone, and granulosa cell number were determined in all follicles $\geqslant 2 \mathrm{~mm}$ in diameter $(n=511)$. In alternate follicles either granulosa cell aromatase activity and theca testosterone content or ${ }^{125} \mathrm{I}$ labelled hCG binding to granulosa and theca were determined. The mean total number of follicles recovered per animal decreased as the follicular phase progressed and a strong positive relationship $(P<0-001)$ existed between follicular diameter and volume on all days. The number of granulosa cells recovered per follicle was variable, and not related to oestrogenic activity of the follicles. Mean follicular fluid oestradiol, testosterone and ${ }^{125}$ I-labelled hCG binding all increased until Day 20 and decreased on Day 21 , whereas mean theca testosterone content, ${ }^{125} \mathrm{I}$-labelled hCG binding to theca tissue and aromatase were all maximal on Day 21. On Days 20 and 21 a subset of 14-16 large follicles was readily distinguishable from the remaining smaller, less oestrogenically active population in each animal. Yet, consistently within these subsets there was a difference in follicular diameter of $\sim 2.0 \mathrm{~mm}$ and also a considerable range of biochemical development even among follicles of equal size. These results indicate asynchrony at the time of recruitment and selection among follicles destined to ovulate and suggest that heterogeneity continues into the immediate preovulatory period.
\end{abstract}

Kelwords: follicle; development: pig; heterogeneity

\section{Introduction}

Follicle recruitment in the gilt occurs from the proliferating pool, after which a process of selection during the follicular phase establishes a group of follicles destined to ovulate. The time of recruitment has been extensively studied in the cyclic gilt and data from experiments involving treatment with exogenous gonadotrophins (Phillippo, 1968; Hunter, 1972; Hunter et al., 1976), electrocautery of follicles (Clark et al., 1979) and unilateral ovariectomy (Coleman \& Dailey, 1979; Clark et al., 1982) suggest that recruitment occurs between Days 14 and 16 of the oestrous cycle. The growth of selected preovulatory follicles during the follicular phase is associated with rapid atresia of smaller follicles and a block to their replacement in the proliferating pool (Robinson \& Nalbandov, 1951; Anderson, 1980; Clark et al., 1982).

Although the gilt has been extensively used to study folliculogenesis in a polytocous species, ovarian material has frequently been obtained from prepubertal gilts treated with PMSG (Ainsworth et al., 1980; Evans et al., 1981) or collected at abattoirs from animals of unknown physiological status. Moreover, ovarian material is often pooled using the simple criterion of

*Reprint requests to Dr M. G. Hunter.

†Present address: Department of Animal Science, University of Alberta, Edmonton, Canada T6G 2PS. 
follicular size (Stoklosowa et al., 1982; Tsang et al., 1985), thus preventing a comparison of data from morphologically similar follicles.

The aim of the present experiment, therefore, was to investigate the maturational changes which occur within and between developing follicles during the follicular phase of a natural oestrous cycle in pigs.

\section{Materials and Methods}

Animals. Twenty prepubertal Landrace $\times$ (Landrace $\times$ Large White) gilts (approximate body weight $80 \mathrm{~kg}$ ) were group-penned and, to stimulate the onset of puberty and to detect oestrus, a vasectomized boar was introduced into each pen twice daily for a minimum period of $1 \mathrm{~h}$. Once gilts had exhibited between 2 and 5 regular oestrous cycles the time of the last observed oestrus (Day 0) for each animal was utilized to calculate the stage of oestrous cycle assuming a 2 I-day cycle length. Five gilts were then slaughtered on Days 16, 18,20 and 21 of the cycle. Slaughter of animals on Day 22/Day 1 of the cycle was discontinued early in the study because morphological changes had started to occur in some of the follicles (Hunter et al., 1989).

Collection and treatment of follicular tissue. The handling and dissection of ovarian tissue, and the collection of follicular fluid and harvesting of granulosa cells were as described previously by Foxcroft et al. (1987). Dissected follicles were ranked according to size, and granulosa cell suspensions from alternate follicles were used to assess extant aromatase activity or ${ }^{125} \mathrm{I}$-labelled hCG binding capacity, also using the methods of Foxcroft et al. (1987). Similarly, theca tissue from alternate follicles was used for ${ }^{125}$ I-labelled hCG binding capacity, or was homogenized in absolute ethanol for subsequent determination of testosterone content of the tissue.

Hormone radioimmunoassays. Measurement of oestradiol in incubation medium was carried out directly according to the method of Foxcroft et al. (1984) but without prior extraction as validated by Foxcroft et al. (1987). The limit of sensitivity of the assay was $6.3 \mathrm{pg} /$ tube and inter- and intra-assay coefficients of variation were 11.7 and $3.6 \%$, respectively. Oestradiol concentration in follicular fluid was also assayed directly and this was validated by comparing the values obtained from a range of samples with and without extraction. The correlation coefficient $(r)$ obtained was $0.993(P<0.001)$, and samples assayed at volumes of $10,20,50$ or $100 \mu \mathrm{l}$ showed parallelism with the standard curve. The limit of sensitivity of the assay was $2.5 \mathrm{pg} /$ tube and inter- and intra-assay coefficients of variation were $9 \cdot 3$ and $2.4 \%$ respectively.

The concentration of progesterone in follicular fluid was determined directly using a modification of the method described by Hunter et al. (1986). The direct assay was validated by comparing the results obtained from a range of samples which were either extracted or measured directly after heating at $70^{\circ} \mathrm{C}$ for $30 \mathrm{~min}$. The correlation coefficient $(r)$ obtained was $0.997(P<0.00 \mathrm{I})$ and samples assayed at volumes of $10,20,50$ or $100 \mu$ l showed parallelism with the standard curve. The limit of sensitivity of the assay was $13.7 \mathrm{pg} /$ tube and inter- and intra-assay coefficients of variation were $6 \cdot 4$ and $4.4 \%$, respectively.

The assay used for the measurement of testosterone in follicular fluid and extracts of theca tissue was as described by Purvis et al. (1974). Follicular fluid samples were extracted with $1 \mathrm{ml}$ diethyl ether by shaking for $20 \mathrm{~min}$ on a multipurpose horizontal shaker. The mean extraction efficiency was $94 \%$ and the limit of sensitivity of the assay was $5 \cdot 2 \mathrm{pg} /$ tube. Samples of follicular fluid assayed at volumes of 20,50 and $100 \mu \mathrm{l}$ confirmed parallelism with the standard curve, and inter- and intra-assay coefficients of variation were $6 \cdot 6$ and $4.0 \%$, respectively. Samples of theca tissue were homogenized and extracted in a final volume of $4 \mathrm{ml}$ double-distilled ethanol, and 100 or $200 \mu \mathrm{l} \mathrm{samples}$ of extract were evaporated to dryness at $37^{\circ} \mathrm{C}$ and reconstituted in assay buffer. Samples assayed at 50,100 and $200 \mu \mathrm{l}$ showed parallelism with the standard curve and the limit of assay sensitivity was $14.1 \mathrm{pg} /$ tube. Inter- and intra-assay coefficients of variation were $13 \cdot 8$ and $12.7 \%$, respectively.

Statistical analysis. To determine relationships between measures within days, the relevant data were subjected to multiple linear correlation and regression analysis. However, since granulosa cells were used to assess either

${ }^{125}$ I-labelled hCG binding or aromatase activity and theca tissue was used to assess ${ }^{125}$ I-labelled hCG binding or testosterone content it was statistically impossible to correlate these measures within follicles. Individual measures on different days were analysed by one-way analysis of variance (ANOVA).

\section{Results}

\section{Follicle number, diameter and volume}

The total number of dissected follicles was 511 , which ranged from 2.0 to $10.5 \mathrm{~mm}$ in diameter with a progressive increase in size from Day 16 to Day 20 (Fig. 1). An inverse relationship $(P<0.001)$ existed among days for the mean follicular diameter (increased from 4.0 to $8.8 \mathrm{~mm}$, 
Table 1) and the mean total number of follicles ( $\geqslant 2.0 \mathrm{~mm}$ diameter) recovered per animal per day (decreased from 36 to 11 , Table 1 ).

A strong positive relationship $(P<0.001)$ existed between follicular diameter and volume for all days (Fig. 2; $r=0.98$, d.f. $=440, P<0.001$; follicular diameter $($ D) $=1.39 \times \sqrt[3]{\mathrm{v}+0.069}$ where $\mathrm{v}=$ volume of follicular fluid). The mean follicular tissue volume (TV; Fig. 2), i.e. the difference between the theoretical volume and actual recorded volume of fluid, in follicles of 4,6 and $8 \mathrm{~mm}$ diameter was $0.42,0.53$ and $0.75 \mathrm{~mm}^{3}$ respectively. This volume increased dramatically on Day 21 to $1.66 \mathrm{~mm}^{3}$ in follicles of $10 \mathrm{~mm}$ diameter.

\section{Number of granulosa cells}

The mean number of granulosa cells $\left(\times 10^{4}\right)$ recovered per follicle was increased from 121.4 to 377.6 for Days 16 to 21 (Table 1). Analysis of follicular diameter with number of granulosa cells established a positive relationship overall (Fig. 3; $r=0.68$, d.f. $=465, P<0.001$ ) and for the populations of follicles from Day $16(r=0.71$, d.f. $=159, P<0.001)$, Day $18(r=0.61$, d.f. $=125$, $P<0.001)$, Day $20(r=0.45$, d.f. $=101, P<0.001)$, and at Day $21(r=0.37$, d.f. $=44, P<0.05)$. The small follicles $(2-3.5 \mathrm{~mm})$ recovered on Days 20 and 21 contained many fragmented cells.

\section{Aromatase activity}

Mean aromatase activity for each day is summarized in Table 1 and was maximal on Day 21 and minimal on Day 16. Differences due to day existed $(P<0.05$ at least) for mean aromatase except for Days 16 and 20 which were similar. Subdivision of the follicles into four diameter classes (Table 2) showed that the largest follicles per day possessed high enzyme activity. Aromatase activity was correlated with follicular fluid oestradiol for all groups (Day 16, $r=0 \cdot 61$, d.f. $=66$, $P<0.001$; Day $18, r=0.44$, d.f. $=60, P<0.001$; Day $20, r=0.68$, d.f. $=41, P<0.001$; Day 21 , $r=0.39$, d.f. $=24, P<0.05)$ and with follicular diameter and volume for Day $18(r=0.66$, d.f. $=60 ; r=0.63$, d.f. $=60, P<0.001)$ and Day $20(r=0.71$, d.f. $=41 ; r=0.74$, d.f. $=41$, $P<0.001)$. Aromatase activity was correlated with testosterone in follicular fluid on Day 20 only $(r=0.64$, d.f. $=41, P<0.001)$.

\section{${ }^{125}$ I-labelled hCG binding to granulosa and theca}

Mean binding to both granulosa and theca is shown in Table 1. Binding to granulosa cells and theca tissue was maximal on Days 20 and 21 respectively and minimal on Day 16 . Differences for binding to granulosa cells were established on Day 16 and all other days $(P<0.001)$ and between Days 18 and $20(P<0.001)$. There was also a difference between binding to theca tissue on Day 16 and all other days $(P<0.001)$, between Days 18 and $20(P<0.01)$, Day $21(P<0.001)$ and between Days 20 and $21(P<0.05)$. Levels of binding to granulosa and theca tissue were correlated on all days: Day 16, $r=0.39$, d.f. $=68, P<0.001$; Day $18, r=0.63$, d.f. $=57, P<0.001$; Day $20, r=0.62$, d.f. $=45, P<0.001$; Day $21, r=0.62$, d.f. $=21, P<0.01$. Binding to granulosa cells was also correlated with number of granulosa cells on Day $16(r=0.49$, d.f. $=68, P<0.001)$, Day $18(r=0.58$, d.f. $=57, P<0.001)$ and Day $21(r=0.58$, d.f. $=21, P<0.01)$ and on Days 16,18 and 20 with follicular diameter $(r=0 \cdot 70$, d.f. $=68,0 \cdot 78$, d.f. $=57$ and $0 \cdot 77$, d.f. $=45$ respectively; $P<0.001)$ and follicular fluid oestradiol concentration $(r=0.48$, d.f. $=68,0.66$, d.f. $=57$ and 0.61 , d.f. $=45$ respectively; $P<0.001$ ). Binding to theca tissue was correlated with follicular fluid oestradiol on all days (Day 16, $r=0.28$, d.f. $=68, P<0.05$; Day $18, r=0.75$, d.f. $=57, P<0.001 ;$ Day $20, r=0.83$, d.f. $=45, P<0.001 ;$ Day $21, r=0.53$, d.f. $=21$, $P<0.05)$ and follicular fluid testosterone and progesterone on Day $18(r=0.47$, d.f. $=57$, $P<0.001 ; r=0.37$, d.f. $=57, P<0.01)$ and Day $20(r=0.69$, d.f. $=45, P<0.001 ; r=0.49$, d.f. $=45, P<0.01)$. 


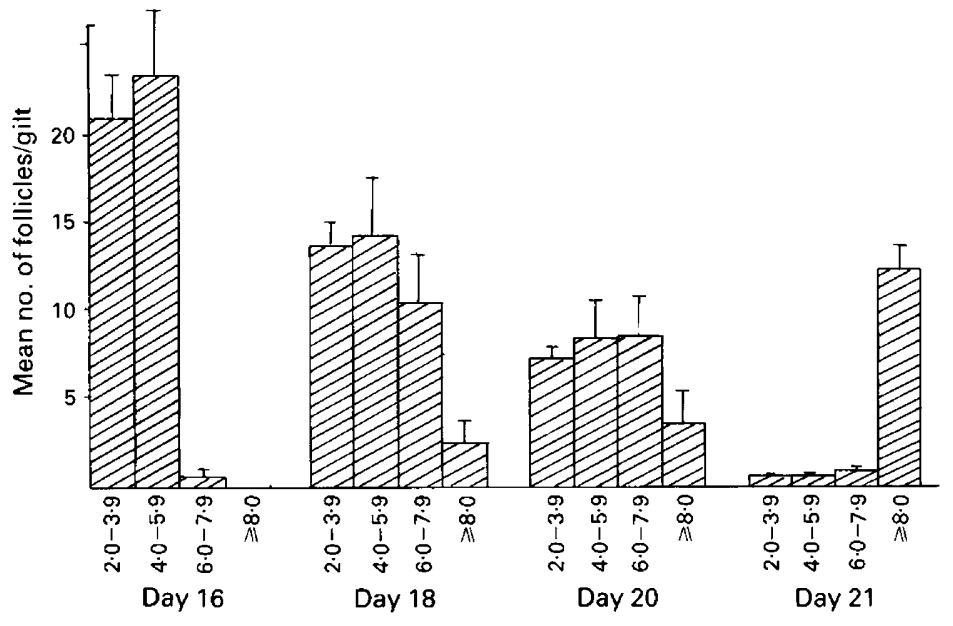

Follicular diameter $(\mathrm{mm})$

Fig. 1. Mean number $( \pm$ s.e.m.) of follicles recovered from individual gilts on 4 days of the oestrous cycle ( 5 gilts/day) and divided into 4 size categories.

Table 1. Overall means and s.e.d. of follicle diameter, granulosa cell number, ${ }^{125} \mathrm{I}$-labelled hCG binding to granulosa and theca tissue, follicular fluid concentrations of oestradiol, testosterone and progesterone, testosterone content of theca tissue and granulosa cell aromatase activity in pig follicles recovered during the oestrous cycle

\begin{tabular}{|c|c|c|c|c|c|}
\hline Variables measured & $\begin{array}{l}\text { Day } 16 \\
(n=180)\end{array}$ & $\begin{array}{l}\text { Day } 18 \\
(n=164)\end{array}$ & $\begin{array}{l}\text { Day } 20 \\
(n=110)\end{array}$ & $\begin{array}{l}\text { Day } 21 \\
(n=57)\end{array}$ & s.e.d. $*$ \\
\hline Diam. (mm) & 3.99 & 4.91 & $5 \cdot 50$ & $8 \cdot 80$ & 0.47 \\
\hline $\begin{array}{l}\text { No. of granulosa cells/follicle } \\
\left(\times 10^{-4}\right)\end{array}$ & $121 \cdot 1$ & $145 \cdot 7$ & {$[46 \cdot 8$} & 376.5 & $44 \cdot 2$ \\
\hline $\begin{array}{l}\text { Granulosa cell aromatase activity } \\
\text { (ng oestradiol } / 2 \mathrm{~h} / \text { follicle) }\end{array}$ & $1 \cdot 13$ & $3 \cdot 70$ & 1.73 & 4.65 & 2.04 \\
\hline $\begin{array}{l}125 \mathrm{I} \text {-labelled hCG binding to granulosa cells } \\
\text { (c.p.m. bound } \times 10^{-3} / \text { follicle) }\end{array}$ & $21 \cdot 2$ & $52 \cdot 1$ & $82 \cdot 9$ & $59 \cdot 7$ & $23 \cdot 5$ \\
\hline $\begin{array}{l}125 \text { I-labelled hCG binding to theca tissue } \\
\text { (c.p.m. bound } \times 10^{-3} / \text { follicle) }\end{array}$ & $7 \cdot 7$ & $24 \cdot 2$ & $38 \cdot 8$ & $53 \cdot 0$ & $14 \cdot 3$ \\
\hline $\begin{array}{l}\text { Oestradiol in follicular fluid } \\
(\mathrm{ng} / \mathrm{ml})\end{array}$ & $22 \cdot 0$ & $110 \cdot 6$ & $235 \cdot 5$ & $102 \cdot 6$ & $89 \cdot 8$ \\
\hline $\begin{array}{l}\text { Testosterone in follicular fluid } \\
(\mathrm{ng} / \mathrm{ml})\end{array}$ & $22 \cdot 3$ & $55 \cdot 8$ & $75 \cdot 7$ & $34 \cdot 3$ & $31 \cdot 4$ \\
\hline $\begin{array}{l}\text { Progesterone in follicular fluid } \\
(\mathrm{ng} / \mathrm{ml})\end{array}$ & $102 \cdot 1$ & $83 \cdot 4$ & $76 \cdot 2$ & 497.2 & $175 \cdot 8$ \\
\hline $\begin{array}{l}\text { Testosterone content of theca tissue } \\
\text { (ng/follicle) }\end{array}$ & 0.06 & $0 \cdot 69$ & 1.76 & $2 \cdot 12$ & 1.36 \\
\hline
\end{tabular}

*Standard error of difference for comparing between means. 


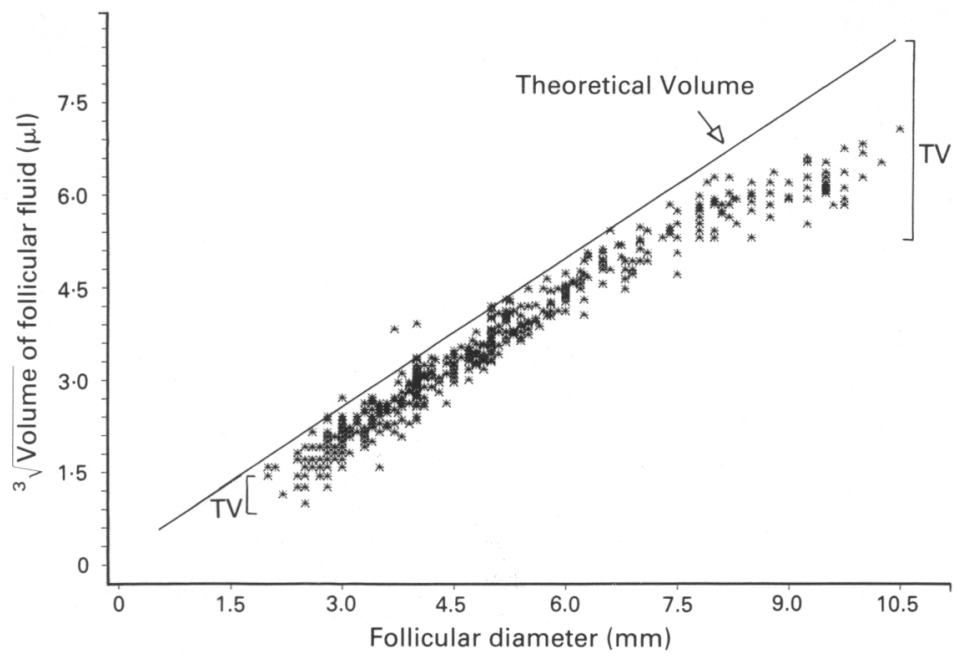

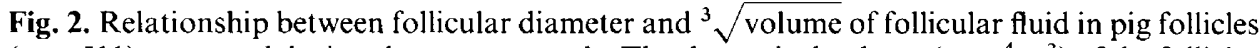
$(n=511)$ recovered during the oestrous cycle. The theoretical volume $\left(\mathrm{v}=\frac{4}{3} \pi \mathrm{r}^{3}\right)$ of the follicles based on the diameter is shown, and the differences between this and the actual volume of follicular fluid measured represents follicular tissue volume (TV).

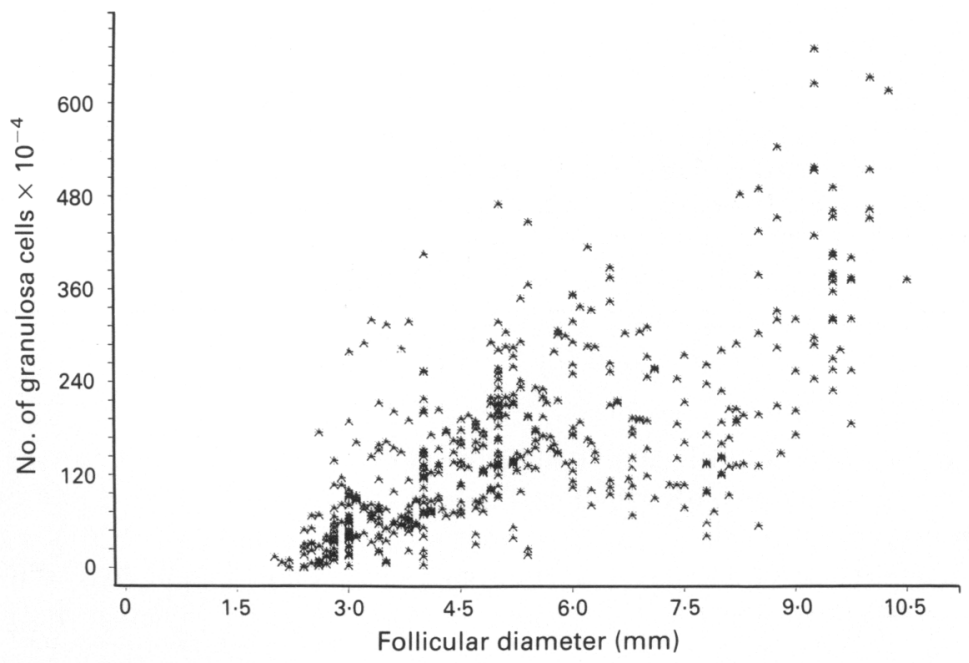

Fig. 3. Relationship between follicular diameter and granulosa cell number in pig follicles $(n=511)$ recovered during the oestrous cycle.

\section{Follicular fluid steroids}

Mean concentrations of follicular fluid steroids for each day are shown in Table 1. Concentrations of oestradiol were maximal on Day 20 and minimal on Day 16 and the difference between these days was significant $(P<0.05)$. Table 2 shows the mean steroid concentrations when the follicles were divided into four size classes. Maximum follicular fluid oestradiol concentrations were observed in the largest follicles per day, similar to aromatase. As reported above, there were 
Table 2. Mean aromatase activity in granulosa cells (ng oestradiol/2 h/ follicle), ${ }^{125}$ I-labelled hCG binding to granulosa and theca tissue (c.p.m. bound $\times 10^{3} /$ follicle), follicular fluid concentrations $(\mathrm{ng} / \mathrm{ml})$ of oestradiol, testosterone and progesterone

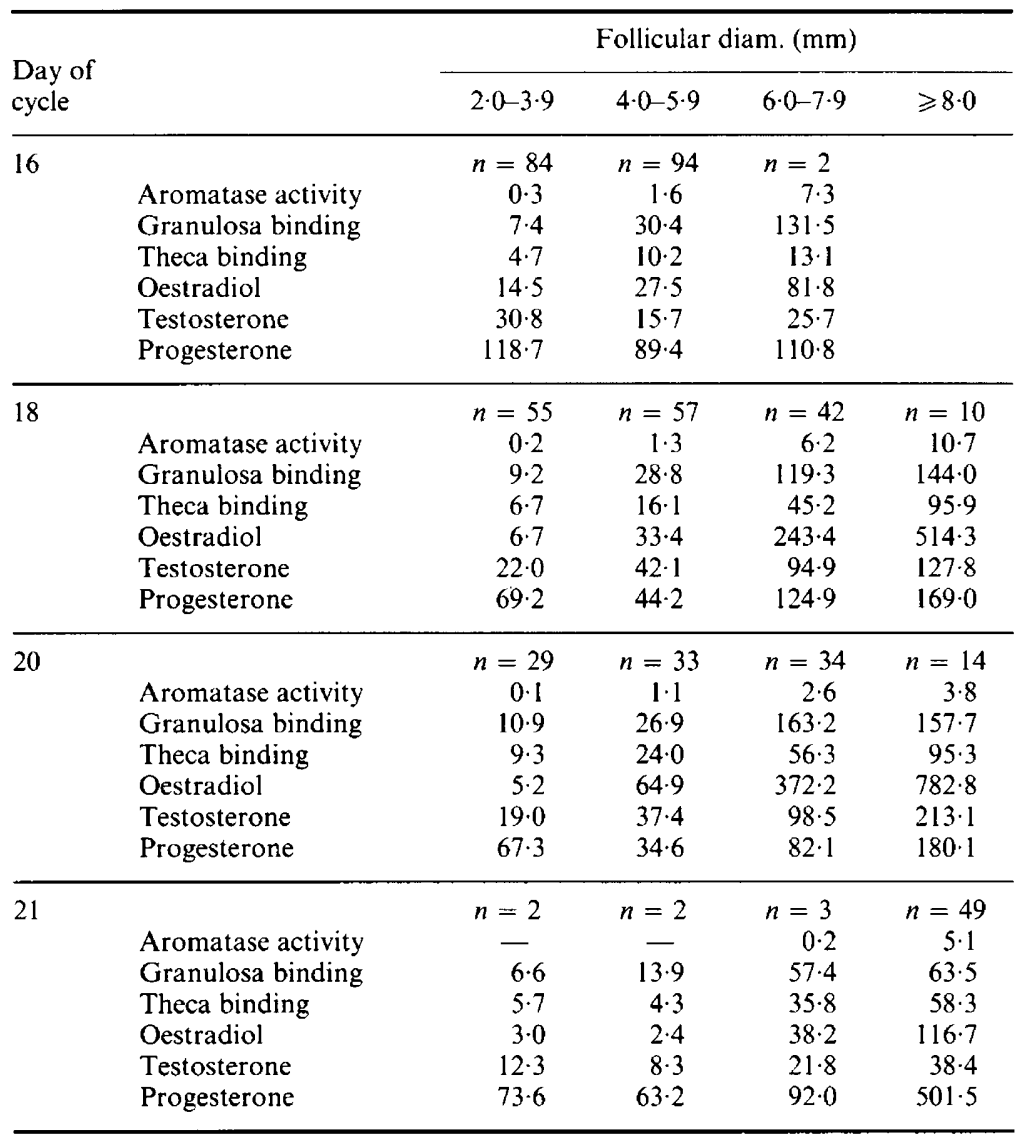

significant correlations between follicular fluid oestradiol, aromatase, binding to granulosa and theca tissue and also on Day 16 with follicular fluid testosterone $(r=0.60$, d.f. $=66, P<0.001)$ and testosterone concentration in theca tissue $(r=0.41$, d.f. $=66, P<0.001)$. Follicular fluid oestradiol was correlated with follicular fluid progesterone on Days 18 and $20(r=0.57$, d.f. $=66$, $r=0.79$, d.f. $=60$ respectively; $P<0.001$ ) and on Day 21 with follicular fluid testosterone $(r=0.87$, d.f. $=24, P<0.001)$.

There were differences between the minimal mean concentrations of testosterone in follicular fluid on Day 16 and the maximal levels on Day $20(P<0.01)$, as well as between Days 16 and 18 $(P<0.05)$. Subdivision of the follicles into four diameter classes ('Table 2 ) showed that testosterone was directly related to diameter on Days 18 and 20 , and, as well as those correlations already described above, testosterone in follicular fluid was highly correlated to tissue testosterone content on Day $21(r=0.93$, d.f. $=27, P<0.001)$ and to follicular diameter on Day $18(r=0.40$, d.f. $=60, P<0 \cdot 01)$. On Day 20 , follicular fluid testosterone was correlated to all measures.

The mean concentration of progesterone in follicular fluid on Day 21 (Table 1) was higher $(P<0.05)$ than on Days 16, 18 and 20 . Within days, progesterone concentrations were highest in the largest follicles of pigs at Days 18, 20 and 21, but in the smallest follicles of the Day-16 animals. 


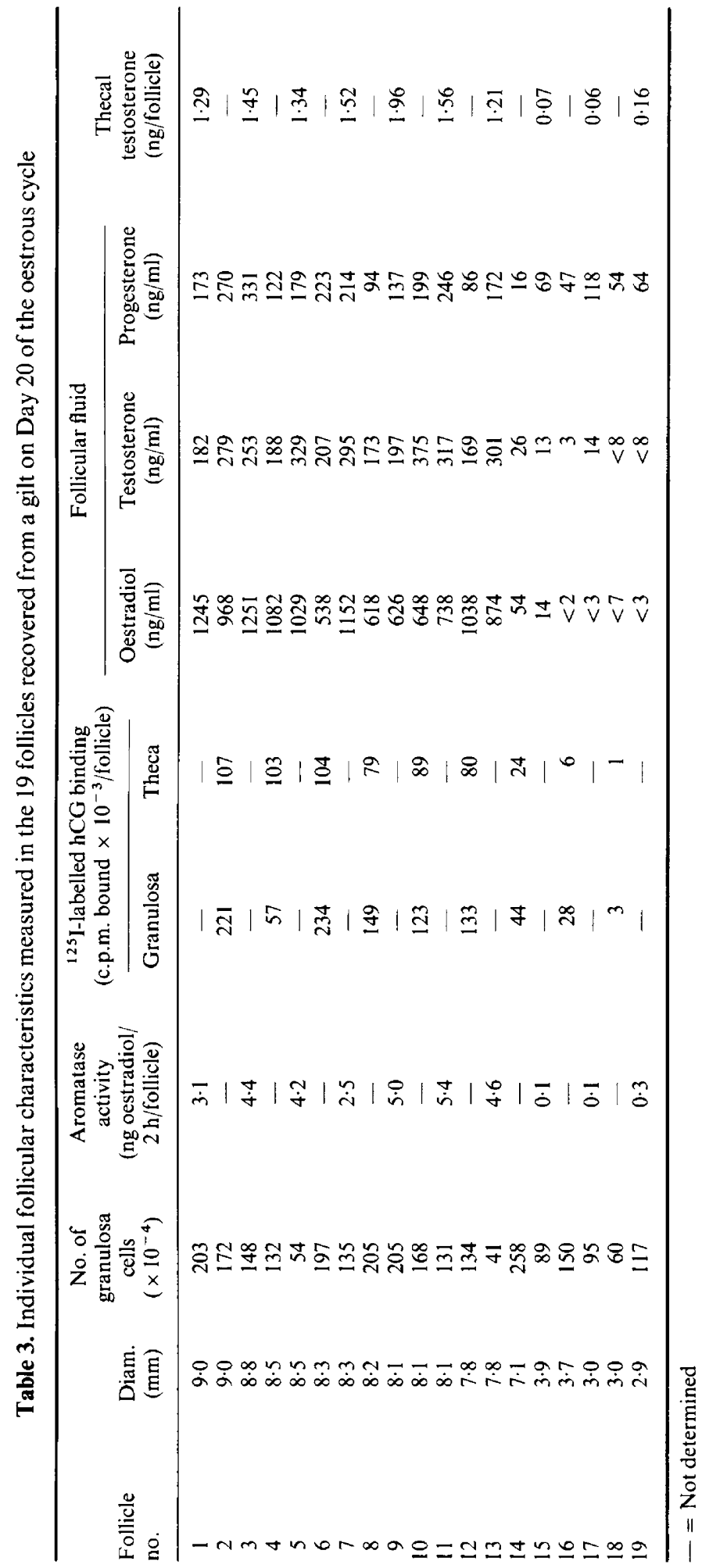




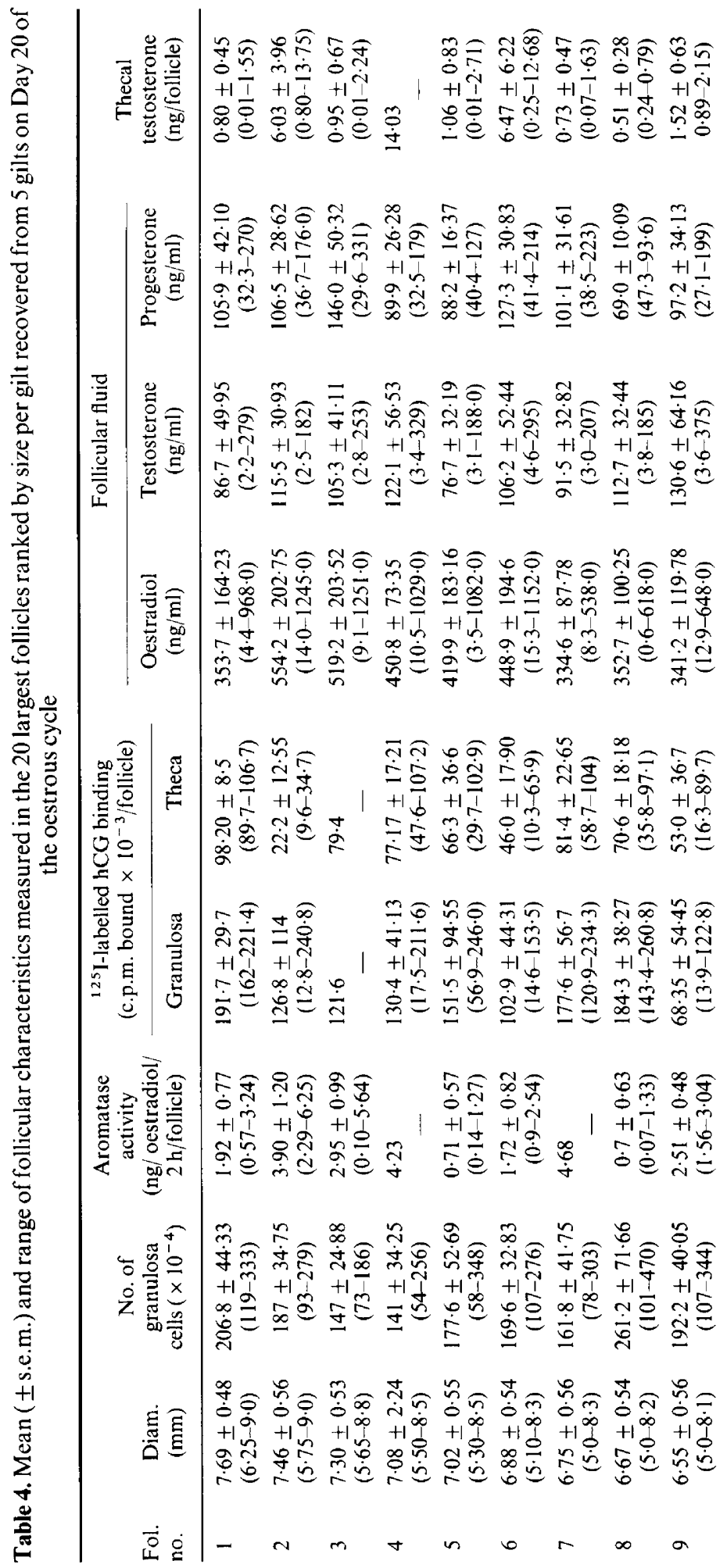




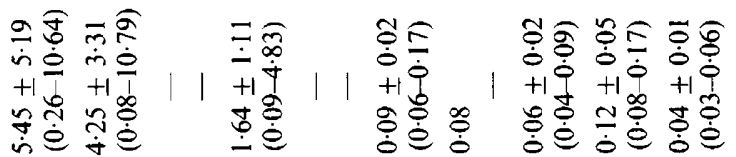

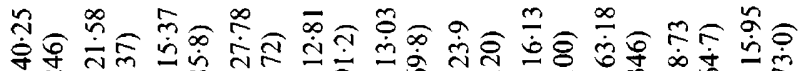

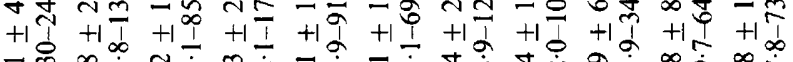

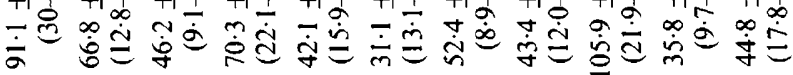

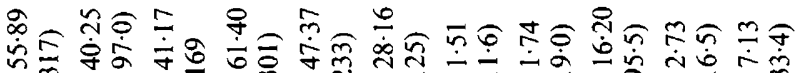

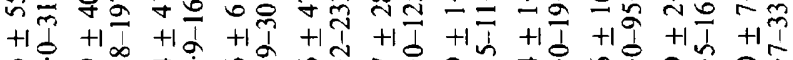
过

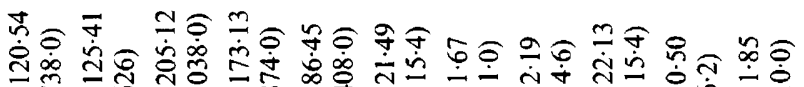
舟

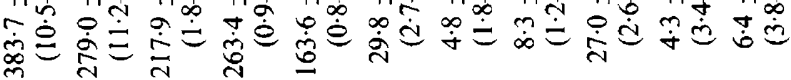

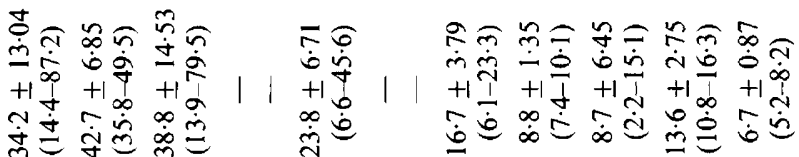

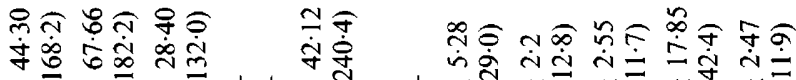

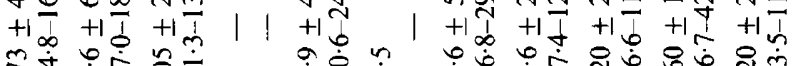

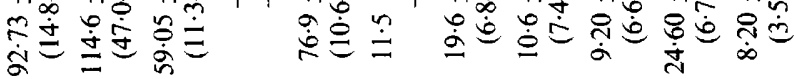

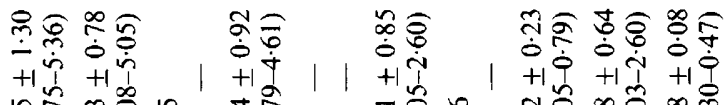

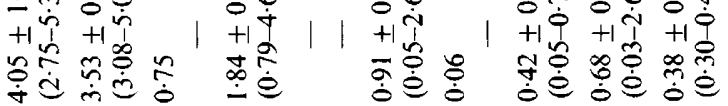

F

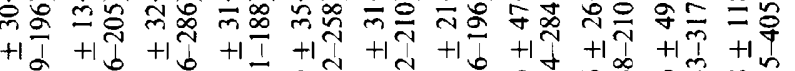

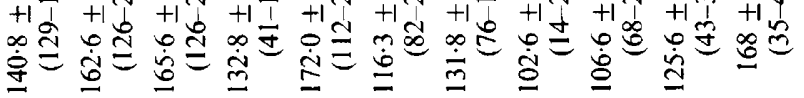

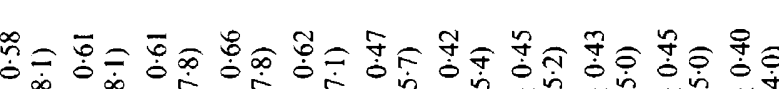

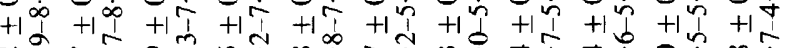

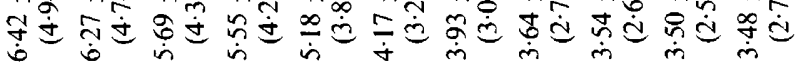

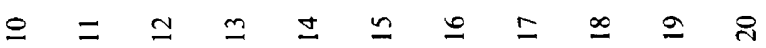


Follicular fluid progesterone was correlated with diameter $(r=0.61$, d.f. $=61, P<0.001)$, aromatase $(r=0.71$, d.f. $=60, P<0.001)$ follicular fluid oestradiol $(r=0.57$, d.f. $=60, P<0.001)$, tissue testosterone content $(r=0.36$, d.f. $=60, P<0.01)$ and binding to granulosa $(r=0.57$, d.f. $=57, P<0.001)$ and theca $(r=0.37$, d.f. $=57, P<0.01)$ on Day 18 and with follicular fluid testosterone on Day $20(r=0.73$, d.f. $=41, P<0.001)$. There was no relationship between progesterone and any follicular measure on Days 16 or 21 .

\section{Theca tissue testosterone content}

As shown in Table 1, there was a progressive increase from a minimum value on Day 16 to a maximum on Day 21 and mean values were different $(P<0.05$ at least) among all days except for Days 20 and 21 . As the cycle progressed, theca tissue testosterone content correlated more strongly with follicular fluid oestradiol $(r=0.41$, d.f. $=66 ; r=0.86$, d.f. $=60 ; r=0.87$, d.f. $=47$; $r=0.93$, d.f. $=27 ; P<0.001$ for Days 16, 18, 20 and 21 , respectively) and with follicular fluid testosterone (Day 18, $r=0.41$, d.f. $=60, P<0.001$ : Day 20, $r=0.82$, d.f. $=47, P<0.001$ : Day $21, r=0.93$, d.f. $=27, P<0.001)$.

\section{Heterogeneity in the follicular population}

All of the various morphological and biochemical characteristics measured in individual follicles from one gilt on Day 20 are shown in Table 3, and the means and variation from the 20 largest follicles from all 5 gilts on Day 20 are shown in Table 4 . These tables clearly illustrate the considerable heterogeneity which existed on Day 20, but was also present throughout the follicular phase.

\section{Discussion}

In the analysis of follicular development among days of the cycle, the large number of follicles $\geqslant 2 \mathrm{~mm}$ diameter present in the Day-16 animals is consistent with previous observations in the cyclic gilt (Robinson \& Nalbandov, 1951; Kirkpatrick et al., 1967; Clark et al., 1973) and confirms that during the luteal phase of the pig oestrous cycle, a proliferating pool of follicles $1-6 \mathrm{~mm}$ in diameter is maintained by a continuous process of development and subsequent atresia. The progressive decrease in follicle number per animal from Day 16 to Day 21 also supports the suggestion of Clark et al. (1973) that during the follicular phase there is a physiological block which prevents the replacement of atretic follicles into the proliferating pool: consequently, by Day 21 only the ovulatory population remained.

Analysis of follicular characteristics within days and within follicles established a significant linear relationship between follicular diameter and volume in the present study. This is consistent with previous observations in the weaned sow (Shaw, 1984) and the ewe (Carson et al., 1981; England et al., 1981) and suggests that, at least in the early to mid-follicular phase in the pig, each of these measures is interchangeable as an estimate of gross morphological development. However, a dramatic increase in tissue volume occurred on Day 21 (Fig. 2) and histological examination of follicles recovered on Day 22 has shown that this is associated with considerable infolding of both the granulosa and theca layers (Hunter et al., 1989).

Although a positive correlation was demonstrated between number of granulosa cells and follicular diameter overall, the strength of this relationship decreased as the follicles matured and attained preovulatory size; there was therefore an unpredictable increase in cell numbers as follicles grew beyond $6 \mathrm{~mm}$ in diameter. This overall pattern agrees with previous results reported for the sheep and human (McNatty, 1982). It should also be emphasized that there was great variability in the number of granulosa cells recovered from follicles of identical diameter regardless of whether 
the follicles were active oestrogenically. The number of granulosa cells present is therefore a poor indicator of health/atresia in medium to large pig follicles.

On Days 20 and 21 a subset of 14-16 large follicles was readily distinguishable from the remaining smaller, less oestrogenically active population in each animal, and yet consistently within these subsets there was a difference in follicular diameter of $\sim 2.0 \mathrm{~mm}$. This suggests that, at the assumed time of ovulation, $36-40 \mathrm{~h}$ after the $\mathrm{LH}$ surge, all follicles will not be at an identical stage of maturity. Possible consequences of such heterogeneity are suggested from the work of Wilde et al. (1987) who showed that a protracted ovulation interval was associated with morphological disparity among littermate embryos. Hence, the asynchronous development of early embryos (Anderson, 1978; Pope et al., 1986) and the subsequent occurrence of embryonic mortality may be a consequence of the initial range of follicular development within the selected ovulatory population.

In the present study aromatase activity in granulosa cells in vitro was related to follicular diameter on Days 16, 18 and 20. However, between Days 18 and 20, the mean aromatase activity actually declined, despite a rise in follicular fluid oestradiol concentrations, suggesting that granulosa aromatase activity is not the limiting factor in the control of oestradiol synthesis at this time. The precipitous decline in follicular fluid oestradiol which occurred on Day 21 in the presence of maximal aromatase activity further supports this theory. The availability of androgen substrate from the theca therefore appears to be of critical importance in maintaining the synthesis of oestradiol and the significant correlation between the testosterone content of the theca tissue and follicular fluid oestradiol throughout the follicular phase strongly supports this concept.

Like aromatase activity, there was a wide variation in follicular fluid steroid concentrations both within and between animals. However, there was a significant relationship between follicular diameter and oestradiol concentrations on Days 16,18 and 20. By Day 20, a subset of follicles with very high concentrations of follicular fluid oestradiol was readily distinguishable, and the 14-16 follicles within this oestrogenically active subset were the largest of the dissected follicles for each Day-20 animal. In accordance with the earlier observations of Channing \& Kammerman (1973, 1974), those highly oestrogenic follicles also bound more ${ }^{125}$ I-labelled hCG than did the adjacent smaller follicles.

The notable change in the follicular fluid steroids of the Day-21 animals (with an increase in progesterone synthesis and a dramatic fall in both oestradiol and testosterone production) was undoubtedly a consequence of the LH surge, as reported from other species (sheep: Moor, 1974; Webb \& England, 1982; cow: Staigmiller et al., 1982; rat: Lieberman et al., 1975). Furthermore, it has been proposed that the LH surge inhibits oestradiol production by reducing aromatase activity (Henderson \& Moon, 1979). However, as the Day-21 group in the present study possessed the highest mean aromatase activity, this theory does not appear to apply to the pig and again suggests that androgen availability is a major limiting factor in oestradiol production.

As for the morphological data, the 14-16 follicles within the selected ovulatory population had readily distinguishable biochemical characteristics on Day 20 , i.e. a high follicular fluid oestradiol: testosterone ratio, elevated granulosa aromatase activity and increased ${ }^{125}$ I-labelled hCG binding to granulosa and theca tissue. However, there was a considerable range of biochemical development among follicles within the same ovary, and this diversity even among follicles of equal size was apparent at all stages of development. Therefore, the pooling of follicles from within the same ovary on the basis of size, in addition to the pooling of follicles of similar size from different animals before in-vitro study, is likely to confound the interpretation of the data obtained.

Although the overall pattern of changing follicular fluid steroids observed in this study compares favourably with the results obtained from previous experiments in PMSG/hCG-primed gilts (Ainsworth et al., 1980; Meinecke et al., 1987), there were some notable differences. Ainsworth et al. (1980) reported that follicular fluid androgen concentrations remained relatively constant throughout preovulatory development, in contrast to a distinct rise and fall in follicular fluid testosterone reported here for naturally cyclic animals. In addition, the maximal concentration of 
follicular fluid oestradiol was notably higher in PMSG/hCG-primed gilts and, in contrast to the cyclic gilts, follicular fluid progesterone was the predominant steroid at $72 \mathrm{~h}$ after PMSG, before the hCG injection and analogous to the Day-20 group in this study. Hence, although the synchronized PMSG/hCG-treated pig represents a well established experimental model, the observed differences between spontaneously and induced ovulating animals should not be overlooked.

It is evident from this study that preovulatory follicular development in a polyovulatory species such as the pig consists of a very complex array of events. The range of morphological and biochemical development on Day 16 indicates that not all follicles destined to ovulate are at the same stage of maturity at the time of recruitment and selection. This asynchrony was highlighted by the marked differences in steroid synthesizing ability of follicles of identical size within the same ovary. A further consequence of the asynchrony in the rate at which follicles become oestrogenically active is the period of time in which follicles are in a 'mature' state before the onset of the preovulatory LH surge. Presumably the high oestrogenic activity of the dominant follicles will provide the trigger for the preovulatory LH surge, and thus set the timing of the surge and ultimately of ovulation. Since the reported timing between oestrogen stimulation and the LH surge in the pig (Edwards \& Foxcroft, 1983) is about $54 \mathrm{~h}$, the activation of the surge mechanism would be expected on Day 18, at a time when the selection of ovulatory follicles is continuing. The interval between the final selection of the least mature ovulatory follicles and the dramatic maturational changes induced by the LH surge must therefore be very limited. This could affect the later development of the oocyte and embryo (Pope et al., 1986; Wilde et al., 1987) and also be causally related to the different populations of functional corpora lutea reported for the pig by Rao \& Edgerton (1984).

On the basis of the characteristics assessed in this study, those follicles destined to ovulate or to become atretic were only readily distinguishable on Day 20 , suggesting that the selection of the preovulatory population continues over the 4-day period from about Day 16 to Day 20 of the cycle and, furthermore, that the selection process involves some initial maturation even in those unselected follicles that ultimately join the atretic pool.

We thank the AFRC and MLC for financial support; the National Hormone and Pituitary Program (NIDDK) for purified hCG; Judith Buckle for excellent technical assistance; and Dr S. S. Lynch for providing the oestradiol antiserum.

\section{References}

Ainsworth, L., Tsang, B.K., Downey, B.R., Marcus, G.J. \& Armstrong, D.T. (1980) Interrelationships between follicular fluid steroid levels, gonadotrophic stimuli and oocyte maturation during preovulatory development of porcine follicles. Biol. Reprod. 23, 621-627.

Anderson, L.L. (1978) Growth, protein content and distribution of early pig embryos. Anat. Rec. 190, 143-153.

Anderson, L.L. (1980) Reproductive cycles. Pigs. In Reproduction in Farm Animals, 4th edn, section IlI, ch. 18 , p. 370 . Ed. E. S. E. Hafez. Lea \& Febiger, Philadelphia.

Carson, R.S., Findlay, J.K., Clarke, I.J. \& Burger, H.G. (1981) Estradiol, testosterone and androstenedione in ovine follicular fluid during growth and atresia of ovarian follicles. Biol. Reprod. 24, 105-113.

Channing, C.P. \& Kammerman, S. (1973) Characteristics of gonadotrophin receptors of porcine granulosa cells during follicle maturation. Endocrinology 92, $53 \mathrm{I}-540$.
Channing, C.P. \& Kammerman, S. (1974) Binding of gonadotropins to ovarian cells. Biol. Reprod. 10, 179-198.

Clark, J.R., Edey, T.N., First, N.L., Chapman, A.B. \& Casida, L.E. (1973) The effects of four genetic groups and two levels of feeding on ovulation rate and follicular development in pubertal gilts. J. Anim. Sci. 36, 1164-1169.

Clark, J.R., Kelly, C.A., Orr, D.E. \& Tribble, L.F. (1979) Folliculogenesis in swine; effects of folliclecautery on subsequent ovulation rate and estrous cycle length. J. Anim. Sci. 49, Suppl. 1, p. 11, Abstr.

Clark, J.R., Brazier, S.G., Wiginton, L.M., Stevenson, G.R. \& Tribble, L.F. (1982) Time of ovarian follicle selection during the porcine estrous cycle. Theriogenology 18, 697-709.

Coleman, D.A. \& Dailey, R.A. (1979) Effect of time of unilateral ovariectomy in gilts. J. Anim. Sci. 49, Suppl., p. 136, Abstr. 
Edwards, S. \& Foxcroft, G.R. (1983) Response of sows to oestradiol benzoate treatment after weaning at two stages of lactation. J. Reprod. Fert. 67, 173 180.

England, B.G., Dahmer, M.K. \& Webb, R. (1981) Relationship between follicular size and antral fluid steroid concentrations at three stages of the estrous cycle in the ewe. Biol. Reprod. 24, 1068-1075.

Evans, G.I., Dobias, M., King, G.J. \& Armstrong, D.T. (1981) Estrogen, androgen, and progesterone biosynthesis by theca and granulosa of preovulatory follicles in the pig. Biol. Reprod. 25, 673-682.

Foxcroft, G.R., Elsaesser, F., Stickney, K., Haynes, N.B. \& Back, H.L. (1984) Ovarian oestrogen, dependent maturation of the luteinising hormone surge mechanism during prepubertal development in the gilt. $J$. Endocr. 101, 371-380.

Foxcroft, G.R., Shaw, H.J., Hunter, M.G., Booth, P.J. \& Lancaster, R.T. (1987) Relationships between luteinising hormone, follicle stimulating hormone and prolactin secretion and ovarian follicular development in the weaned sow. Biol. Reprod. 36, 175-191.

Henderson, K.M. \& Moon, Y.S. (1979) Luteinization of bovine granulosa cells and corpus luteum formation associated with loss of androgen aromatizing ability. J. Reprod. Fert. 56, 89-97.

Hunter, M.G., Southee, J.A., McLeod \& Haresign, W. (1986) Progesterone pretreatment has a direct effect on GnRH-induced preovulatory follicles to determine their ability to develop into normal corpora lutea in anoestrous ewes. $J$. Reprod. Fert. 76, 349-363.

Hunter, M.G., Grant, S.A. \& Foxcroft, G.R. (1989) Histological evidence for heterogeneity in the development of preovulatory pig follicles. J. Reprod. Fert. 86, $165-170$.

Hunter, R.H.F. (1972) Ovarian response of the pig to gonadotrophins injected at different stages of the oestrous cycle. Proc. 7 th Int. Congr. Anim. Reprod. \& A.I., Munich 2, 10531057.

Hunter, R.H.F., Cook, B. \& Baker, T.G. (1976) Dissociation of response to injected gonadotropin between the Graafian follicle and oocyte in pigs. Nature, Lond. 260, 156-158.

Kirkpatrick, R.L., Howland, B.E., First, N.L. \& Casida, L.E. (1967) Ovarian and pituitary gland changes in gilts on two nutrient energy levels. J. Anim. Sci. 26, 358-364.

Lieberman, M.E., Barnea, A., Bauminger, S., Tsafriri, A., Collins, W.P. \& Lindner, H.R. (1975) LH effect on the pattern of steroidogenesis in cultured graafian follicles of the rat: dependence on macro-molecular synthesis. Endocrinology 96, 1533-1542.

McNatty, K.P. (1982) Ovarian follicular development from the onset of luteal regression in human and sheep. In Follicular Maturation and Ovulation, pp. 1-18. Eds R. Rolland, E. V. Van Hall, S. G. Hillier, K. P. McNatty \& J. Schoemaker. Excerpta Medica, Amsterdam.

Meinecke, B., Gips, H. \& Meinecke-Tillman, S. (1987) Steroid hormone content of the developing preovulatory porcine follicle. In Follicular Growth and Ovulation Rate in Farm Animals, pp. 207-213. Eds J. F. Roche \& D. O. Callaghan. Martinus Nijhoff, Dordrecht.

Moor, R.M. (1974) The ovarian follicle of the sheep: inhibition of oestrogen secretion by luteinising hormone. J. Endocr. 61, $455-463$.

Phillippo, M. (1968) Superovulation in the pig. $A d v$. Reprod. Phvsiol. 3, 147-166.

Pope, W.F., Lawyer, M.S., Nara, B.S. \& First, N.L. (1986) Effect of asynchronous superinduction on embryo survival and range of blastocyst development in swine. Biol. Reprod. 35, 133-137.

Purvis, K., Illius, A.W. \& Haynes, N.B. (1974) Plasma testosterone concentrations in the ram. J. Endocr. 61, 241-253.

Rao, Ch. V. \& Edgerton, L.A. (1984) Dissimilarity of corpora lutea within the same ovaries or those from right and left ovaries of pigs during the oestrous cycle. J. Reprod. Fert. 70, 61-66.

Robinson, G.E. \& Nalbandov, A.V. (1951) Changes in the hormone content of swine pituitaries during the estrual cycle. J. Anim. Sci. 10, $469-478$

Shaw, H.J. (1984) Control of ovarian function in lactating and weaned sow's. Ph.D. thesis, University of Nottingham.

Staigmiller, R.B., England, B.G., Webb, R., Short, R.E. \& Bellows, R.A. (1982) Estrogen secretion and gonadotropin binding by individual bovine follicles during estrus. J. Anim. Sci. 55, 1473-1482.

Stoklosowa, S., Gregoraszezuk, E. \& Channing, C.P. (1982) Estrogen and progesterone secretion by isolated cultured porcine thecal and granulosa cells. Biol. Reprod. 26, 943-952.

Tsang, B.K., Ainsworth, L., Downey, B.R. \& Marcus, G.J. (1985) Differential production of steroids by dispersed granulosa and theca interna cells from developing preovulatory follicles of pigs. J. Reprod. Fert. 74, $459-471$.

Webb, R. \& England, B.G. (1982) Identification of the ovulatory follicle in the ewe: associated changes in follicular size, thecal and granulosa cell LH receptors, antral fluid steroids and circulating hormones in the preovulatory period. Endocrinology 110,873-881.

Wilde, M.H., Xie, S., Nephew, K.P. \& Pope, W.F. (1987) The relationship between ovulation and morphological variation of day 11 swine embryos. Biol. Reprod. 36 (Suppl.), 60, Abstr. 41 .

Received 3 August 1988 